УДК 621.36

DOI https://doi.org/10.32838/2663-5941/2021.3/11

Скакун О.В.

Український науково-дослідний інститут спеціальної техніки та судових експертиз

Служби безпеки України

\title{
Воскресенський В.Б.
}

Український науково-дослідний інститут спеціальної техніки та судових експертиз Служби безпеки України

Сивобородько А.В.

Український науково-дослідний інститут спеціальної техніки та судових експертиз Служби безпеки України

\section{ОГЛЯД ПОРТАТИВНИХ АНАЛІЗАТОРІВ СПЕКТРУ ТА АНАЛІЗАТОРІВ СИГНАЛІВ, ЩО МОЖУТЬ БУТИ ВИКОРИСТАНІ ПІД ЧАС ВИЯВЛЕННЯ ПОБІЧНИХ ЕЛЕКТРОМАГНІТНИХ ВИПРОМІНЮВАНЬ}

У статті надані приклади класифікації побічних електромагнітних випромінювань та наведень (ПЕМВН) в різних країнах світу та технічних каналів можливого витоку інформації. Розкриті параметри витоку інформації за рахунок ПЕМВН, їхні найменування, одиничі вимірювання та фізичні величини. Показано, щзо апаратний контроль реально наявних та потениійних загроз несанкиіонованого доступу і зняття інформації, що має грифи обмежсення доступу, - одна із найбільш важсливих задач у сфері інформаційної безпеки, особливо в теперішній час. Авторами відмічено, що апаратний контроль можливо здійснювати як спеціалізованими засобами вимірювальної техніки (ЗBT), так і ЗВТ універсального призначення.

Основний матеріал дослідження в запропонованій статті присвячений оглядовому аналізу портативних аналізаторів спектру та аналізаторів сигналів, що можуть бути використані під час виявлення ПЕМВН, які властиві засобам персональних електронно-обчислювальних машин (ПЕОМ): флешносіям, магнітним дискам, принтерам, клавіатурам та моніторам. Вказано, щяо перехоплення ПЕМВН базується на широкому використанні найрізноманітніших 3BT, засобів аналізу і реєстрації інформації; антено-фідерних пристроїв; широкосмугових антенних підсилювачів.

Проаналізовано особливості параметрів сучасних аналізаторів спектру та сигналів, також внесено пропозиції щодо їх вибору. Наданий лаконічний, але досить трунтовний огляд зазначених портативних ЗВТ від наступних провідних виробників: аналізатори спектру компанії Rohde\&Schwarz $R \& S \circledR F S H$ 4/8/13/20 (Німеччина); ручні аналізатори сигналів FieldFox фiрми Keysight Technologies, що входить до корпорації Agilent Technologies (США); прилади 500 серії від компанії MICRONIX (Японія); портативний аналізатор сигналів IDA 3106 з функиіями моніторингового приймача та пеленгаиії від консориіуму NARDA (Німеччина).

Також у статті наведені марки та параметри активних антен, які автори рекомендують використовувати як антено-фідерниі пристрої в комплекті із ЗВТ універсального призначення для контролю ПЕМВН.

Ключові слова: побічні електромагнітні випромінювання та наведення, канали витоку інформації, аналізатор спектру, аналізатор сигналів, радіосигнали, роздільна спроможність, роздільна здатність, амплітуда, частота, вимірювання, частотний діапазон.

Постановка проблеми. Сучасні масиви інформації, що містять державну таємницю або комерційні, технологічні секрети, проходять етап обробки на персональних електронно-обчислювальних машинах (ПЕОМ), яким властиві побічні електромагнітні випромінювання та наведення (ПЕМВН).

Проблемам виявлення ПЕМВН приділяють належну увагу відповідні правоохоронні структури, міністерства та організації в країнах всього цивілізованого світу. Приклад класифікації ПЕМВН поданий на рис. 1.

Фізичні процеси, що відбуваються в технічних засобах і системах, призначених для передачі, обробки, приймання і збереження інформації, при їх функціонуванні, створюють у навколишньому середовищі побічні електромагнітні, акустичні, оптичні та інші випромінювання, що пов'язані 3 обробкою інформації. Такі процеси носять назву - технічні канали витоку інформації (ТКВI). Приклад класифікації ТКВІ подано на рис. 2. 


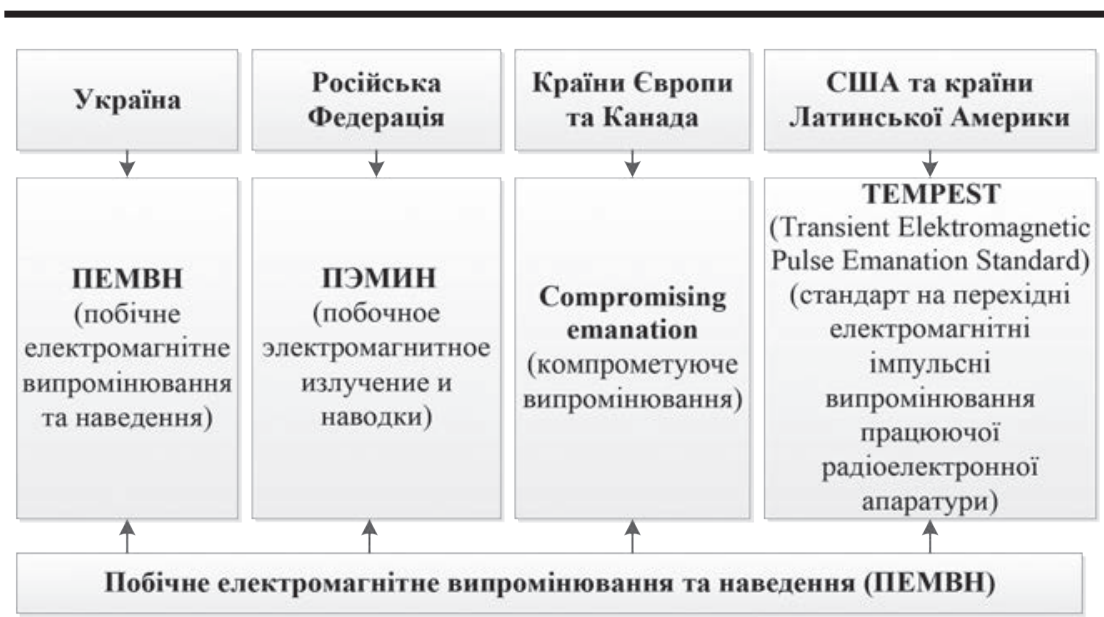

Рис. 1. Приклад класифікації ПЕМВН в країнах світу

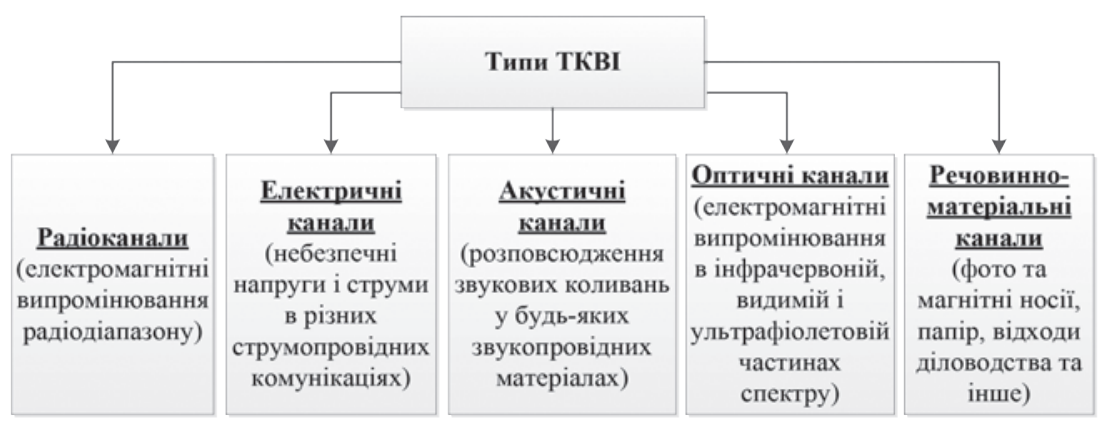

Рис. 2. Приклад класифікації ТКВІ

Водночас перелік каналів витоку інформації за рахунок ПЕМВН тауий [1]: безпосередньо в оперативній або постійній пам'яті ПЕОМ; на з'ємних магнітних, магнітооптичних, лазерних і інших носіях; на зовнішніх пристроях зберігання інформації колективного доступу (RAID-масиви, файлові сервери і тому подібне); на екранах пристроїв відображення (дисплеї, монітори, консолі); у пам'яті пристроїв введення/виведення (принтери, графічні пристрої, сканери); у пам'яті управляючих пристроїв; в лініях зв'язку комп'ютерних мереж.

Канали витоку інформації утворюються як при роботі ПЕОМ, так і в режимі очікування. Джерелами таких каналів $\epsilon$ [2]: електромагнітні поля; струми, що наводяться, і напруга в кабельних системах (живлення, заземлення і сполучних); перевипромінювання інформації, що обробляється, на частотах паразитної генерації елементів і пристроїв технічних засобів ПЕОМ; перевипромінювання оброблюваної інформації, на частотах контрольно-вимірювальної апаратури.

У зв'язку із вищезазначеними проблемами виникає задача аналізу можливості витоку інформації, що обробляється на ПЕОМ через ПЕМВН та його апаратного контролю.

Необхідно враховувати такі особливості радіотехнічних каналів витоку із засобів цифрової електронної техніки [3]: джерелами небез- печного сигналу (з точки зору можливості витоку інформації) $€$ елементи, вузли і провідники технічних засобів забезпечення виробничої діяльності, а також радіоелектронна та електронна апаратура; кожне джерело небезпечного сигналу за певних умов може утворити технічний канал витоку інформації; кожна електронна система, що містить в собі сукупність елементів, вузлів і провідників, потенційно може утворити значну кількість технічних каналів витоку інформації.

Кожен $з$ цих каналів, залежно від конкретної реалізації елементів, вузлів і виробів в цілому, матиме певний прояв, специфічні характеристики і особливості утворення, пов' язані з умовами розташування і виконання.

Перелік можливих параметрів витоку інформації за рахунок ПЕМВН показаний в табл. 1.

Отже, потрібно реалізувати апаратний контроль можливого витоку інформації, що обробляється на ПЕОМ через ПЕМВН.

Аналіз останніх досліджень і публікацій. Дослідженням проблемних питань обгрунтування вибору та рекомендацій щодо застосування сучасних ЗВТ універсального призначення, що можуть бути використані під час виявлення ПЕМВН, займалися такі вітчизняні науковці, як В. Макаренко [4, с. 50-53], В. Воскресенський, А. Сивобородько, В. Ковальчук, О. Скакун, М. Борисова $[5$, с. $44-48,6$, с. $73-77,7$, с. 74-78]. Існує велика кількість праць зарубіжних дослідників. Досить грунтовнимиєкниги А. АфонськоготаВ.Дьяконова [8; 9]. Також доступні інформаційно-довідкові технічні матеріали, які розміщені на сайтах провідних виробничих та дистрибьюторських компаній різних країн, що спеціалізуються на приладобудівній тематиці.

Постановка завдання. Мета цієї статті надати короткі описи та викласти певні рекомендації щодо застосування універсальних засобів вимірювальної техніки (в комплекті із антенофідерними пристроями та радіочастотними кабелями) як засобів апаратного контролю під час виявлення ПЕМВН.

Виклад основного матеріалу дослідження. Комплексний характер актуальних загроз національній безпеці в інформаційній сфері потребує визначення інноваційних підходів до формування системи захисту та розвитку інформаційного 
Перелік можливих параметрів витоку інформації за рахунок ПЕМВН

\begin{tabular}{|c|c|c|c|}
\hline $\begin{array}{c}\text { № } \\
\text { 3/I }\end{array}$ & Назва параметру ПЕМВН & $\begin{array}{c}\text { Одиниця } \\
\text { вимірювання }\end{array}$ & $\begin{array}{c}\text { Оріснтовна величина } \\
\text { параметру ПЕМВН }\end{array}$ \\
\hline 1. & Частотний діапазон & Гц & $10 \div 5 \times 10^{9}$ \\
\hline 2. & Рівень випромінювання в ближній зоні & дБ & $10 \div 30$ \\
\hline 3. & $\begin{array}{c}\text { Орієнтовна максимальна відстань прийому сигналів } \\
\text { випромінювання }\end{array}$ & м & $100 \div 400$ \\
\hline 4. & Тактова частота складових компонентів ПЕОМ & ГГц & $1,5 \div 4,8$ \\
\hline 5. & Номер досліджуваної гармоніки тактової частоти & № & $4 \div 50$ \\
\hline
\end{tabular}

простору в умовах глобалізації та вільного обігу інформації [10].

Апаратний контроль наявних та потенціийних загроз несанкиіонованого доступу і зняття інформації, що має грифи обмеження доступу - одна із найбільш важливих задач у сфері інформаційної безпеки функціонування державних структур [5, с. 44-48; 11].

Апаратний контроль можливо здійснювати, як спеціалізованими засобами вимірювальної техніки (ЗВТ), так і ЗВТ універсального призначення. Приклад класифікації засобів наведено на рис. 3.

До спеціалізованих ЗВТ належать, наприклад, комплект радіомоніторингу типу «Пластун», професійний трьохдіапазонний індикатор поля iPROTЕСТ 1216, комплект виявлення засобів несанкціонованого зняття інформації типу «OSCOR», нелінійні локатори типу «ORION» (рис. 4).

Зразками обладнання універсального призначення, що забезпечують належний рівень контролю та захисту каналів передачі інформації, є сучасні аналізатори спектра (аналізатори сигналів) укомплектовані необхідними радіочастотними кабелями та антеннофідерними пристроями. До універсальних ЗВТ, наприклад, належать портативні ручні аналізатори

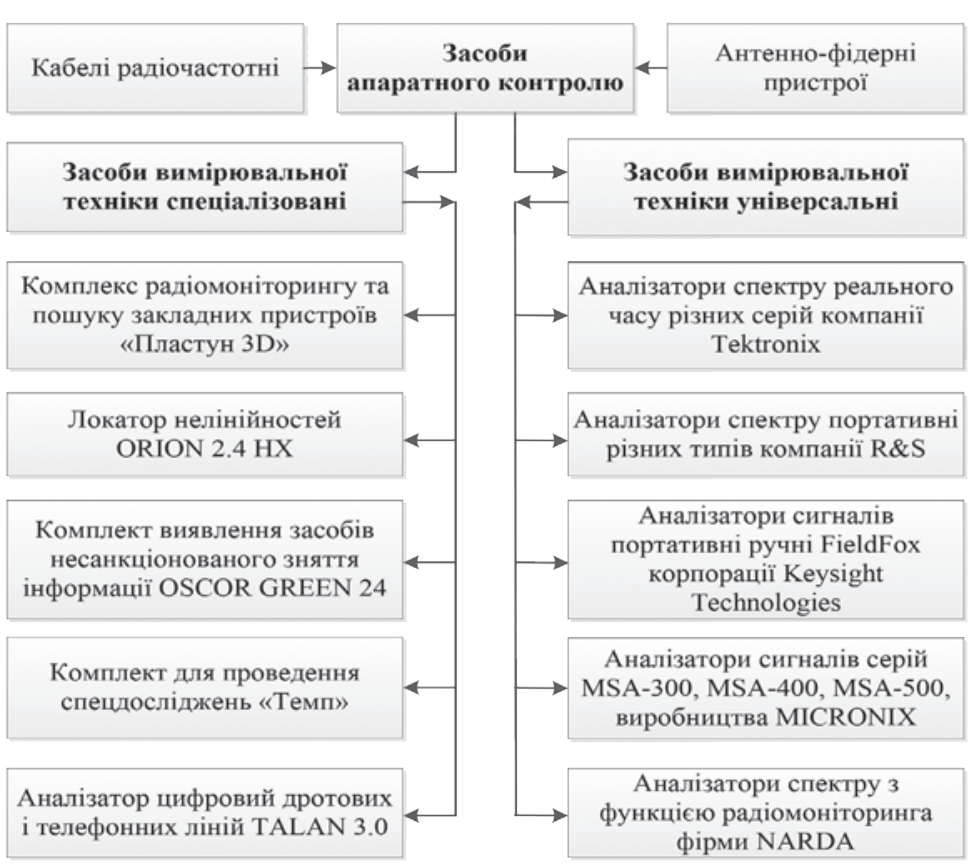

Рис. 3. Приклад класифікації засобів апаратного контролю для виявлення загроз несанкціонованого доступу і зняття інформації

сигналів FieldFox виробництва компанії Keysight Technologies [12], портативні аналізатори спектра FSH 4/8/13/20 корпорації Rohde\&Schwarz [13], аналізатори спектра реального часу серій RSA5000B, RSA6100A, RSA7100A фірми Tektronix, аналізатори сигналів MICRONIX [14].

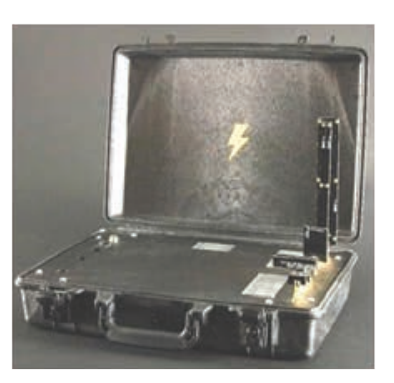

a

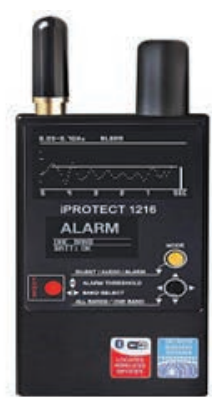

6

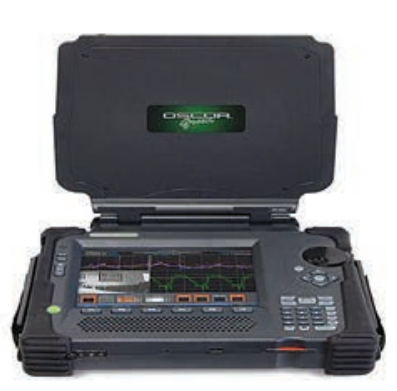

B

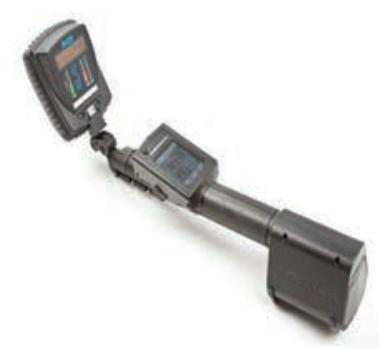

$\Gamma$

Рис. 4. Приклади спеціалізованих 3ВТ: а) комплект радіомоніторингу «Пластун»; б) індикатор поля іPROTECT 1216; в) комплект «OSCOR»; г) нелінійний локатор «ORION» 
Аналізатор спектру (від англ. spectrum analyzer) - пристрій для одержання спектрів фізичних процесів, який дозволяє визначати амплітуду й частоту спектральних компонент, що входять до складу аналізованого процесу. Найважливіша характеристика приладу - роздільність (роздільна спроможність, роздільна здатність): найменший інтервал частот між двома спектральними лініями, які ще розділяються аналізатором. Використовуються для аналізу властивостей радіосигналів, для дослідження характеристик радіопристроїв [15].

На думку авторів, охарактеризовані далі за текстом статті портативні повнофункціональні аналізатори можуть бути рекомендовані до застосування при апаратному контролі ПЕМВН.

Портативні аналізатори спектру компанії Rohde\&Schwarz R\&S ${ }^{\circledR} F S H \quad 4 / 8 / 13 / 20$ (Німеччина) - це конструктивно зручні та міцні прилади, рекомендовані до експлуатації в польових умовах. Мала вага, простий та зрозумілий інтерфейс управління, також великий набір вимірювальних функцій перетворюють ці ЗВТ в незамінний інструмент для тих користувачів, кому потрібен надійний та ефективний прилад для робіт під відкритим небом.

$\mathrm{R} \& \mathrm{~S}^{\circledR} \mathrm{FSH}$ - це, в першу чергу, аналізатор спектру, але залежно від встановлених опцій він може бути також вимірювачем потужності, кабельним та антенним тестером, двохпортовим векторним аналізатором електричних ланцюгів. Прилад (рис. 5) забезпечує виконання трьох найважливіших функцій високочастотного аналізу, наприклад його можливо використовувати для технічного обслуговування або налагодження радіопередаючих систем, перевірки кабелів та антен, оцінювання якості сигналу в радіокомунікаційних комплексах. Також його успішно застосовують для вимірювання напруженості електромагніт-

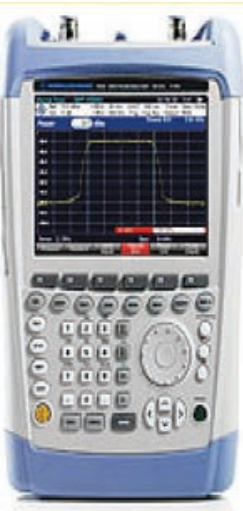

Рис. 5. Зовнішній вид аналізаторів спектру
1 Гц до 3 МГц. Максимальна смуга демодуляції до 20 МГц (при аналізі сигналів LTE); вимірювальні функції для всіх основних задач по введенню в експлуатацію та обслуговуванню радіопередаючих систем; вбудовані трекінг-генератор та КСВН-міст із інжектором живлення досліджуваного пристрою по коаксіальній лінії; двопортовий векторний аналізатор електричних ланцюгів; легкозамінна літієво-іонна батарея на 4,5 години роботи; збереження результатів вимірювань на SD-картці; інтерфейси USB та локального ланцюга - для дистанційного управління та переносу вимірюваних даних; міцний вологозахищений корпус для роботи в польових (полігонних) умовах; зручність експлуатації приладів за рахунок легкої ваги (не перевищує 3 кг із акумуляторною батареєю) та доступності функціональних клавіш; П3 R\&S ${ }^{\circledR} \mathrm{FSH} 4 \mathrm{View}$ для простого документування результатів вимірювань; П3 R\&S ${ }^{\circledR} \mathrm{FSH}$ WIZARD - функція автоматичних вимірювань для налагодження оптимальних параметрів та підвищення точності вимірювань.

Отже потенційні користувачі мають доступ до 8 моделей аналізатора $\mathrm{R} \& \mathrm{~S}^{\circledR} \mathrm{FSH}$, які розраховані на різні сфери застосування і різні частотні діапазони.

Моделі iз вбудованим трекінг-генератором можливо використовувати для визначення передаточних характеристик кабелів, фільтрів, підсилювачів та інше. Виробляються також моделі із вбудованими трекінг-генератором та КСВН-мостом, які можливо використовувати для вимірювання відстані до місця пошкодження кабелю, векторного аналізу електричних ланцюгів та інше.

Весь модельний ряд оснащений попереднім підсилювачем (з функціями налагодження та регулювання), який дозволяє вимірювати сигнали дуже низького рівня.

Портативні ручні аналізатори сигналів FieldFox від компанії KeysightTechnologies корпорації AgilentTechnologies (США). Фірма KeysightTechnologies для полігонних випробувань пропонує сімейство ручних аналізатоpiв FieldFox. Надвисокочастотні аналізатори спектру - моделі N9935A, N9936A, N9937A, N9938A; повнофункціональні 2-х портові векторні аналізатори ланцюгів моделі N9925A, N9926A, N9927A, N9928A; комбіновані високочастотні та надвисокочастотні аналізатори - моделі N9913A, N9914A, N9915A, N9916A, N9917A, N9918A.

Вищезазначені прилади функціонують в діапазоні від 30 кГц до 26,5 ГГц. Всі вони відповідають 
стандарту MIL - PRF - 28800F Class 2. Пилезахищена конструкція без вентиляторів та вентиляційних отворів підвищує надійність приладів при експлуатації в широкому спектрі температур (від мінус 10 до плюс $55{ }^{\circ} \mathrm{C}$ ), впливу солоного та вологого оточуючого середовища. Усі аналізатори відповідають вимогам стандарту MIL-STD-810G, Method 511.5, Procedure 1 для роботи у вибухонебезпечних середовищах.

Аналізатори спектру забезпечують надвисоку точність вимірювання рівня сигналу $(+/-0,5$ дБ) без попереднього їх прогрівання. Аналізатори ланцюгів мають найточніші методи калібрування (повне 2-х портове калібрування по невідомій перемичці). Тестування антено-фідерних систем виконується без зовнішніх калібрувальних комплектів (функції QuickCal та CalReady). Прилади оснащені відслідковуючими генераторами та вбудованими незалежними джерелами сигналів 3 діапазоном частот від 30 кГц до 26,5 ГГц [12].

Аналізатори FieldFox можуть використовуватися в різноманітних сферах діяльності: для полігонних випробувань; для тестування супутникового зв'язку; для налагодження надвисокочастотної ретрансляції; для технічного обслуговування систем зв'язку військового призначення; для технічного обслуговування радіолокаційних систем та для вирішення інших задач. Засоби вимірювальної техніки FieldFox інтегрують в одному компактному корпусі функції декількох приладів. Окрім того, вони забезпечують гнучкість у використанні коштів: придбавши прилад, сконфігурований під певні задачі, потім можливо його доповнити іншими функціональними можливостями.

Наведемо короткий перелік технічних можливостей ручних аналізаторів сигналів FieldFox (рис. 6): аналізатор антено-фідерних пристроїв; аналізатор спектру; відслідковуючий генератор та вбудоване незалежне джерело сигналів; вбудований вимірювач потужності; вимірювання потужності за допомогою вимірювачів потужності 3 шиною USB; вимірювання параметрів імпульсів за допомогою вимірювачів пікової потужності 3 шиною USB; векторний вольтметр.

Аналізатори сигналів FieldFox розроблені у відповідності з потребами користувачів для виконання їх повсякчасної діяльності в різних умовах експлуатації, вони відповідають жорстким вимогам військових стандартів MIL-PRF-28800F Class 2 та MIL-STD-810G, Method 511.5, Procedure 1.

Аналізатори сигналів MICRONIX (Японія) нової лінійки серії MSA-500 на сьогодні серійно виробляються компанією MICRONIX. У приладах одночасно реалізовані система реального часу на основі швидкого перетворення Фур'є та звичайна система розгортки, що для комплексного рішення $\epsilon$ досить унікальним явищем [8].

Наведемо деякі переваги системи реального часу: забезпечується можливість аналізу спектра нестійких сигналів, таких як пакетні сигнали або шум; передбачена можливість аналізу в часовій області, наприклад аналіз залежності потужності від часу, частоти від часу, фази від часу, квадратурних сигналів (I і Q); велике значення має функція запуску (trigger), можливий режим захоплення неперіодичних спектрів, що дуже рідко 3'являються. Система розгортки має наступні переваги: можливість встановлення широкого частотного інтервалу дозволяє спостерігати за широким діапазоном частот; прилади можуть бути укомплектовані відслідковуючими генераторами; можливе вимірювання електромагнітних завад (ЕМЗ) відповідно до вимог стандартів; режим розгортки реалізовано у вигляді системи звичайного аналізатора спектра, що зрозумілий користувачам та забезпечує велику кількість варіантів застосування.

Виробник пропонує п'ять моделей аналізаторів сигналів: MSA-538, MSA-538TG, MSA-538E, MSA-558, MSA-558E.

Типовий представник зазначеної лінійки виробів - аналізатор MSA-538TG з вбудованим тригергенератором, що дозволяє проводити автоматичне калібрування (самоналагоджування) приладу. Цей аналізатор має діапазон робочих частот від 20 кГц до 3,3 ГГц; діапазон частот функції запуску від 5 МГц до 3,3 ГГц; середній рівень власних шумів складає - 162 дБм/Гц, а в режимі реального часу становить - 140 дБм/Гц.

Технічні характеристики, які властиві всім типам аналізаторів сигналів серії MSA-500 (рис. 7): опорний рівень встановлюється від +10 дБм до -60 дБм; в системі реального часу можуть бути використані функції запуску: за рівнем потужності каналу, за рівнем потужності, за рівнем проміжної частоти (IF) та за зовніш-

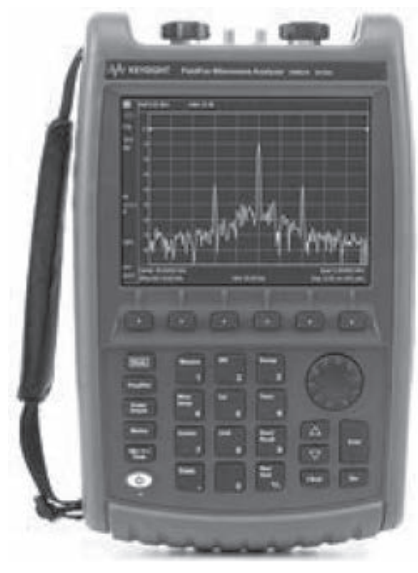

Рис. 6. Зовнішній вид ручних аналізаторів FieldFox 
ньою подією; аналіз в системі реального часу на основі функції Overwrite (перезапис) із швидкістю 720 кадрів за секунду дозволяє не пропустити навіть паразитні спектри, що рідко з'являються; максимальна ширина частотного інтервалу в режимі реального часу складає $20 \mathrm{MГц;} \mathrm{літій-іон-}$ ний акумулятор типу МB400 забезпечує функціонування протягом чотирьох годин; гарантується виконання шести функцій вимірювань, чотирьох функцій обчислень, вимірювання за допомогою маркерів та функції пошуку пікових значень; вага приладу разом з акумуляторною батареєю не перевищує 1,8 кг; габаритні розміри не перевищують $162(Ш)$ х 71(В) х 265(Г) мм [16, с. 184].

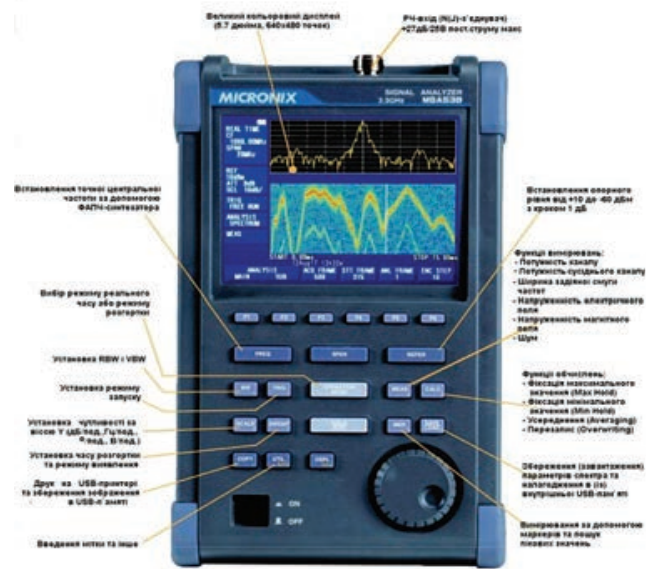

Рис. 7. Аналізатор сигналів серії MSA-500

Прилади серії MSA-500 мають широкий спектр застосування, зокрема й в експертних дослідженнях у сфері захисту інформації.

Отже, універсальному ЗВТ - аналізатору сигналів MSA-500 властиві функції такого ж рівня, що й лабораторним ЗВТ, а саме функції: вимірювання потужності каналу; потужності сусіднього (суміжного) каналу; ширини смуги частот, що експлуатується; напруженості електричного поля; напруженості магнітного поля; шуму; обчислень MaxHold (фіксація максимального значення), MinHold (фіксація мінімального значення), Averaging (знаходження середнього значення), Owerwrite (перезапис); вимірювання за допомогою маркерів; пошуку пікових значень.

Застосування приладів серії MSA-500 дозволить оптимізувати та покращити проведення експертних досліджень у сфері захисту інформації, зокрема й виконувати комплексні перевірки наявних та потенційних загроз несанкціонованого доступу та зняття інформації.

Засоби вимірювальної техніки компанії NARDA (Німеччина). Портативний аналізатор сигналів 3 функціями моніторингового приймача та пеленгації NARDA IDA-3106 (рис. 8) призначений для радіомоніторингу спектру частот в діапазоні частот 9 кГц - 6 ГГц, аналізу інтерференції сигналів [17].

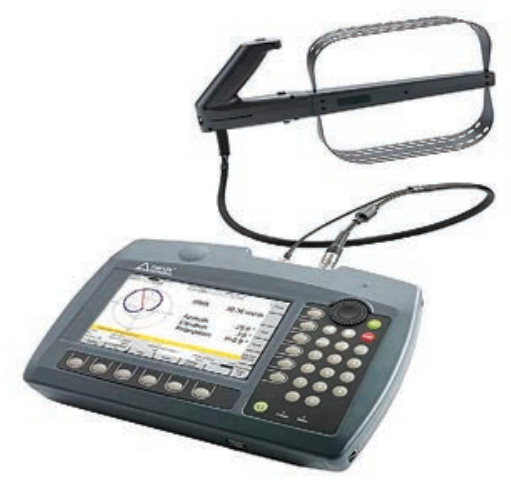

Рис. 8. Портативний моніторинговий приймач

Активні направлені антени, оснащені вбудованим компасом. Призначені для визначення напряму радіовипромінювання в межах частотного діапазону від 20 МГц до 6 ГГц; висока швидкість сканування (12 ГГц/с); смуга аналізу в режимі реального часу $32 \mathrm{MГц;} \mathrm{режим} \mathrm{пелен-}$ гації $з$ автоматичним визначенням азимута; вбудований приймач GPS i електронний компас для полегшення визначення напряму радіовипромінювання; функція SMARTDF дозволяє отримати результати тріангуляції при пеленгації і автоматично обчислювати місце розташування джерела випромінювання; удароміцний малогабаритний легкий корпус (менше 3 кг).

IDA-3106 - високочутливий аналізатор сигналів, що поєднує чудову чутливість 3 високою швидкістю моніторингу і вбудованими компонентами геолокації, включаючи подвійний компас i картографічне ПО. Портативна система розроблена для використання як у польових умовах, так і для локалізації випромінювань в приміщенні. Дана система $\epsilon$ ідеальним рішенням в ситуаціях, що вимагають підвищеної мобільності і швидкого розгортання. У список основних завдань моделі IDA-3106 входить виявлення, класифікація i локалізація високочастотних сигналів. Унікальна направлена антена оснащена вбудованим електронним компасом і системою обміну даних між антеною і аналізатором, що значно спрощує роботу. Відмінними характеристиками портативного приладу є: функція горизонтального сканування (Horizontal Scan) 3 автоматичним визначенням азимуту і функція SMARTDF для автоматичного обчислення місця джерела випромінювання. 
Удароміцний, ергономічний дизайн захищає прилад від механічних пошкоджень, дії поганих погодних умов і високочастотних випромінювань. IDA-3106 був розроблений з метою знаходження та визначення будь-яких високочастотних випромінювань. Можливі сфери застосування приладу: 1) виявлення завад, обумовлених впливом промислових об'єктів; 2) захист комунікацій в період проведення надзвичайно важливих заходів; 3) локалізація аварійних (рятувальних) радіопередавачів; 4) локалізація ВЧ пригнічувачів; 5) контроль спектру радіочастот; 6) локалізація мініатюрних передавачів; 7) моніторинг спектру сигналів; 8) пошук випромінювань в ближній зоні.

Режими роботи: 1) аналізатор спектру; 2) пеленгація; 3) вимір потужності в каналі; 4) вимір рівня сигналу; 5) режим осцилографа; 6) I/Q демодуляція [17].

Режим аналізатора спектру дозволяє дуже швидко сканувати весь діапазон частот, також ідеально підходить для виявлення, контролю і аналізу будь-яких видів сигналів. Повне сканування діапазону 6 ГГц відбувається за 500 мс навіть при високій роздільній здатності із смугою пропускання 500 кГц. При роботі спільно 3 направленими антенами Narda наднизький рівень шуму що становить до -30 дБ $\mu \mathrm{B} / \mathrm{м}$ дозволяє виявити малопотужні передавачі або ПЕМВН. Роздільна здатність смуг пропускання 3 діапазоном частот від 10 Гц до 20 МГц відповідає вимогам сучасних стандартів до безпровідних комунікацій або імпульсним сигналам. Максимальні (max) середні (avg) і мінімальні (min) значення огинаючої спектру дозволяють класифікувати природу сигналу. Усі підозрілі сигнали можна ізолювати за допомогою функцій зручного маркера, потім сигнали можна збільшити i перенаправити в інший режим роботи приладу для детальнішого аналізу. Представлення даних у вигляді СПЕКТРОГРАМИ («ВОДОСПАД») $\epsilon$ ідеальним рішенням для тривалого контролю ВЧ спектру і визначення наявних короткочасних сигналів і сигналів із стрибаючою частотою. Спектрограма також дозволяє визначити джерела випромінювання зі змінною потужністю i/або зі змінною смугою. Найбільш відмітною характеристикою $є$ можливість одночасної реєстрації середньоквадратичних значень (RMS) і пікових значень спектрограми. На великому 7-дюймовому кольоровому екрані результати можуть бути представлені у вигляді: спектру спектрограми, спектру i спектрограми в одному вікні, таблиці з найбільш потужними сигналами.

Активні антени для контролю ПЕМВН. У комплекті із універсальними ЗВТ для апарат- ного контролю ПЕМВН можливо використовувати такі зразки антено-фідерних пристроїв:

1. Антена вимірювальна магнітного поля П6-119 - призначена для вимірювання напруженості магнітного поля в діапазоні частот від 9 кГц до 30 МГц. Рекомендована для метрологічних додатків і завдань оцінки електромагнітної сумісності (ЕMC) та ПЕМВН (наявні високі динамічні характеристики; діаметр рамки антени - 599 мм; можлива експлуатація в лабораторних і польових умовах, а також на рухомих засобах; конструкція передбачає можливість кріплення антени на опору будь-якого типу).

Технічні характеристики: діапазон частот 9 кГц - 30 МГц; коефіцієнт калібрування від 10 до 27 дБ (1/м); чутливість по полю, не гірше 25 мкА/м; межі похибки $\pm 1,5$ дБ; напруга живлення $\pm 15 \mathrm{~B}$; споживаний струм \pm 100 мА; габарити $84 \times 599 \times 690$ мм; вага 2,5 кг.

\section{2. Антена вимірювальна магнітного поля} П6-219 призначена для вимірювання напруженості магнітного поля в діапазоні частот від 20 кГц до 600 МГц. Рекомендована для метрологічних додатків і завдань оцінки ЕМС і ПЕМВН (в наявності високі динамічні характеристики; діаметр рамки антени - 100 мм; можлива експлуатація в лабораторних і польових умовах; конструкція передбачає можливість кріплення антени на опору будь-якого типу).

Технічні характеристики: діапазон частот 20 кГц - 600 МГц; коефіцієнт калібрування від 10 до -6 дБ (1/м); чутливість по полю, не гірше 25 мкА/м; межі похибки \pm 2 дБ; напруга живлення $\pm 12( \pm 15)$ В; споживаний струм \pm 50 мА; габарити $191 \times 88 \times 69$ мм; вага 0,5 кг.

3. Антена вимірювальна електричного поля П6-120 призначена для вимірювання напруженості електричного поля в діапазоні частот від 9 кГц до 30 МГц. Рекомендована для метрологічних додатків і завдань оцінки ЕМС і ПЕМВН (наявні високі динамічні характеристики; можлива експлуатація в лабораторних і польових умовах, а також на рухомих засобах).

Технічні характеристики: діапазон частот 9 кГц - 30 МГц; коефіцієнт калібрування від -14 до 4,5 дБ (1/м); чутливість по полю, не гірше 25 мкА/м; межі похибки $\pm 1,5$ дБ; напруга живлення \pm 15 В; споживаний струм \pm 100 мА; габарити 1476×688×688 мм; вага 5 кг.

Також автори вважають за необхідне відмітити, що сайти www.Tektronix.com, www.ru.tektronix. com, www.vdmais.kiev.ua та багато інших дають змістовну інформацію про різні ручні радіопелен- 
гаторні антени, наприклад такі як Alaris Df-A0047. Застосування зазначених антен дає можливість оптимізувати час пошуку місця ПЕМВН.

Кабелі радіочастотні - найкращий варіант застосування із нормованими радіочастотними характеристиками. Це унеможливить отримання різного роду невизначеностей при пошуку та вимірюванні джерел ПЕМВН.

Висновки. На базі аналізу викладеного матеріалу можливо дійти таких висновків:

1) задача аналізу можливості витоку інформації, що обробляється на ПЕОМ, через виникнення ПЕМВН надзвичайно актуальна на теперішній час;

2) апаратний контроль наявних та потенційних загроз несанкціонованого доступу та зняття інформації, що має грифи обмеження доступу, - надважливе питання у просторі інформаційної безпеки функціонування державних та комерційних структур;

3) здійснення апаратного контролю ПЕМВН за допомогою ЗВТ універсального призначення дає можливість їх подвійного використання, як для вирішення зазначених задач, так і для виконання інших вимірювань;

4) матеріали, викладені в цій статті, можуть слугувати логічним доповненням до загальної класифікації засобів негласного отримання інформації та методик їх виявлення, розглянутих у дослідженні українських науковців К. Клименка, О. Костенка та О. Ільченка [18].

\section{Список літератури:}

1. Зайцев А.П., Шелупанов А.А. Технические средства и методи защиты информации : учебное пособие для вузов. Москва : Горячая линия-Телеком, 2009. 616 с.

2. Носов, В.В., Манжай, А.В. Організація та забезпечення безпеки інформації : навчальний посібник. Харків : ХНУВС, 2007. $216 \mathrm{c}$.

3. Ленков С.В. Методы и средства защиты информации. Киев : Арий, 2010. Т. І. Несанкционированное получение информации. $464 \mathrm{c}$.

4. USB-анализаторы спектра реального времени Tektronix. CHIP NEWS Украина. Инжсенерная микроэлектроника. 2017. № 2. С. 50-53.

5. Воскресенський В.Б., Сивобородько А.В., Ковальчук В.А. Використання аналізаторів спектра реального часу для апаратного контролю у сфері інформаційної безпеки. Актуальні проблеми управління інформаційною безпекою держави. Збірник матеріалів VI науково-практичної конферениії (Київ, 19 березня 2015 року). y 2-x частинах. Київ : Центр навчальних, наукових та періодичних видань Національної академії СБ України. 2015. С. 44-48. Частина 2, 256 с.

6. Воскресенський В.Б., Скакун О.В., Сивобородько А.В. Портативні аналізатори спектра реального часу, як апаратні інструменти забезпечення контролю інформаційної безпеки на тактичному рівні. Актуальні проблеми управління інформаиійною безпекою держави. Збірник матеріалів VII науково-практичної конференції (Київ, 18 березня 2016 року). У 2-х частинах. Київ : Центр навчальних, наукових та періодичних видань Національної академії СБ України, 2016, Ч. 1. С. 73-77.

7. Воскресенський В., Борисова М., Сивобородько А. Огляд портативних USB-аналізаторів, що можуть бути використані при вирішенні науково-технічних та судово-експертних завдань. CHIP NEWS Украина. Инженерная микроэлектроника. 2018. № 2. С. 74-78.

8. Афонский А.А., Дьяконов В.П. Цифровые анализаторы спектра, сигналов и логики. Москва : СолонПресс, 2009. 247 c.

9. Афонский А.А., Дьяконов В.П. Электронные измерения в нанотехнологиях и микроэлектронике / Под ред. проф. В.П. Дьяконова Москва : ДМК Пресс, 2011. 688 с.

10. Про рішення Ради національної безпеки і оборони України від 29.12.2016 «Про доктрину інформаційної безпеки України : Указ Президента України 25.02.2017 №47/2017 / База даних «Законодавство України / ВР України». URL : http://zakon2.rada.gov.ua/laws/show/47/2017.

11. Хорошко В.А. Методы и средства защиты информации. Юниор, 2003. 504 с.

12. Keysight Technologies. Контрольно-измерительные решения. Каталог 2016.377 с. URL : https://prist.ru (дата звернення: 22.03.2021).

13. Контрольно-измерительное оборудование. Каталог 2016/2017. URL : www.rohde-schwarz.ru (дата звернення: 22.03.2021).

14. Офіційний сайт компанії MICRONIX. URL : https://www.micronix-jp.com.

15. Вакуленко М.О., Вакуленко О.В. Тлумачний словник із фізики. Київ : Видавничо-поліграфічний центр «Київський університет», 2008. 767 с.

16. Борисова М.О., Воскресенський В.Б. Портативні ручні аналізатори сигналів серії MSA-500. Приладобудування: стан і перспективи : збірник матеріалів XIX міжнародної науково-технічної конферениіï (Київ, 13-14 травня 2020 р.). Київ : КПI ім. Ігоря Сікорського, 2020. С. 184. URL : https:/ela.kpi.ua/ handle/123456789/33597 Секція 11. Метрологія та інформаційно-вимірювальні технології. 
17. Електронний ресурс фірми «Інкотел Сістемс». URL : https://incotel.com.ua.

18. Клименко К.О., Костенко О.В., Ільченко О.М. Загальна класифікація засобів негласного отримання інформації та методик їх виявлення. Вчені записки Таврійського національного університету імені B.I. Вернадського. Серія: Технічні науки. № 6. 2020. С. 6-15.

\section{Skakun O.V., Voskresenskiy V.B., Sivoborodko A.V. REVIEW OF PORTABLE SIGNAL ANALYZERS THAT CAN BE USED TO DETECT SPURIOUS ELECTROMAGNETIC RADIATION}

The article provides examples of classification of incidental electromagnetic radiation and guidance $(I E M R G)$ in different countries and technical channels of possible information leakage. The parameters of information leakage due to IEMRG, their names, units of measurement and physical quantities are revealed. It is shown that hardware control of real and potential threats of unauthorized access and removal of information marked as restricted access is one of the most important tasks in the field of information security, especially now. The authors note that hardware control can be carried out both by specialized measuring equipment $(M E)$ and $M E$ for universal use.

The main research material in the proposed article is devoted to a review analysis of portable spectrum analyzers and signal analyzers that can be used to detect IEMRG, which are inherent in personal electronic computers: flash drives, magnetic disks, printers, keyboards and keyboards. It is stated that the interception of IEMRG is based on the widespread use of various ME, means of analysis and registration of information; antenna-feeder devices; broadband antenna amplifiers.

The peculiarities of the parameters of modern spectrum and signal analyzers are analyzed, and proposals for their selection are also made. A concise but fairly thorough review of these portable ME from the following leading manufacturers is provided: spectrum analyzers from Rohde \& Schwarz $R$ \& S®FSH 4/8/13/20 (Germany); manual fieldFox signal analyzers from Keysight Technologies, part of Agilent Technologies (USA); devices of the 500 series from the MICRONIX company (Japan); portable IDA 3106 signal analyzer with monitoring receiver and direction finding functions from the NARDA consortium (Germany).

The article also presents the brands and parameters of active antennas, which the authors recommend to use as antenna-feeder devices complete with ME universal purpose for IEMRG control.

Key words: incidental electromagnetic radiation and guidance, information leakage channels, spectrum analyzer, signal analyzer, radio signals, resolution, resolving power, amplitude, frequency, measurements, frequency range. 